\title{
Peduncular Hallucination Status Secondary to Thalamic Stroke: Brief Case Report and Review of the Literature
}

\section{Carmen Maura Carrillo de Albornoz Calahorro ${ }^{1 *}$, Margarita Guerrero-Jiménez ${ }^{1}$ and Luis Gutiérrez-Rojas ${ }^{2,3}$}

${ }^{1}$ Psychiatry Service, Hospital Virgen de las Nieves Hospital, Granada, Spain

${ }^{2}$ Psychiatry and Neurosciences Research Group (CTS-549), Institute of Neurosciences,

University of Granada, Granada, Spain

${ }^{3}$ Psychiatry Service, Hospital Campus de la Salud, Granada, Spain

*Corresponding Author: Carmen Maura Carrillo de Albornoz Calahorro, Department

of Psychiatry, Psychiatry Service, Hospital Virgen de las Nieves, Granada, Spain.
Received: August 05, 2020

Published: August 31, 2020

(C) All rights are reserved by Carmen Maura

Carrillo de Albornoz Calahorro., et al.

\begin{abstract}
Background: The role of thalamus in the pathogenesis of visual and auditory hallucinations has been described as "Peduncular Hallucinosis". This kind of hallucinations has been reported to be associated with thalamic injury joined to midbrain structures damage. Hallucinations are filled with vivid images of animals and colorful characters in motion and in many cases are associated with sleep disorders. Despite these characteristics, patients generally distinguish them as not real.

Case Report: The present case has the distinction of having characteristics somewhat different from those described in published cases. In the first place, it is the case of the longest duration published up to date, 5 years, secondly, contrary to what usually happens, the patient does not criticize the objects and understands them as real

Conclusions: We present an updated review about literature published and redefinition of the concept the particular characteristics of this rare syndrome. When facing hallucinatory cases of an organic type, especially in patients with cardiovascular risk factors, it is important to rule out rare syndromes such as Charles Bonnet or hallucinations of thalamic origin.
\end{abstract}

Keywords: Perceptive Distortion; Peduncular Hallucinosis; Status; Thalamus; Thalamic Stroke; Visual Hallucinosis

\section{Introduction}

'Peduncular hallucinosis' (PH) is used to describe vivid and complex hallucinations in the presence of lesions of the midbrain and/or thalamus [1]. Since the first publication by Jean Lhermitte in 1922 of his paper on hallucinosis, peduncular type has been described as a purely visual phenomenon [2]. In this paper he described this rare syndrome as the cerebral peduncle cap syndrome describing psycho-sensory disturbances in midbrain lesions.

It was first described in a 72-year-old woman with hallucinations of strangely, colorfully attired people and groups of children which occurred at dusk. These were associated with no alteration of conscious state and neurological signs consistent with an infarct of the pons and midbrain [2]. Lhermitte's colleague Von Bogaert coined the term 'peduncular hallucinosis' in his description of a patient with a similar presentation, together with post-mortem neuropathological evidence of midbrain infarction [3]. The term 'peduncular' was not intended as a reference solely to the cerebral peduncles but to the whole midbrain and its surrounds. De Morsier extended the syndrome to include thalamic lesions, and re-established the lesion model for PH [4] whereas his predecessors had suggested sleep-wake cycle disturbances and ego dissolution as the likely origins. $\mathrm{PH}$ has subsequently been associated with a range of differing central nervous system pathologies, including vascular and infectious midbrain [5], pontine [6] and thalamic lesions [7], local subarachnoid hemorrhage [8], compression by local $[9,10]$ and distal tumors [11], basilar migraine [12], basilar vascular hy- 
poplasia [13] and following regional surgical [14] or angiographic interventions [15].

The case we present has the peculiarity of having characteristics somewhat different from those described frequently in the cases published to date. One of the most special characteristics for which we have decided to publish it is the duration of the syndrome, until the date we have not found any other published case of superior duration. Our case does not criticize distorted perceptions of reality and understands them as part of his everyday life.

As a result, we will review the published literature and redefine the particular characteristics of this rare clinical picture.

\section{Case Report}

61-year-old male enters nephrology ward due to grade 3 renal failure and frequent falls during last month caused by "losing strength" in the legs. In addition, he presented a history of a thalamic brain accident evidenced by CT as a $4 \mathrm{~mm}$ lesion in the medial thalamus which had taken place 5 years ago and that had led to time-space disorientation, general discomfort, nausea and vomiting to the present. He had no history of personal or familiar previous psychiatric pathology.

Upon admission, the patient had no objectionable alterations in mental state, so the study and treatment of neuro and nephrological pathology began. The hydro electrolytic and acid base balance alterations were corrected and thoracic and cerebral abdominal imaging tests were performed trying to clarify "the loss of strength".

Head and neck MRI showed a hypoplasia of the A1 segment on the right Anterior Cerebral Artery and of the P1 on the right Posterior Cerebral Artery. To complete the study, we performed abdominal ultrasound, chest X-ray, pulmonary scintigraphy as well as doppler study of lower limbs that did not provide any relevant information. It was therefore determined that sudden episodes of falls were due to drops attacks: abrupt falls without prodromal symptoms trigger factors or loss of consciousness and with instantaneous recovery to baseline status.

Unexpectedly, during his stay in the hospital ward, the patient began to verbalize that for five years, just after suffering the thalamic infarction, he had begun to see images of his everyday life: "I saw my own son in the kitchen of the house eating a snack and did not understand why he did not offer me to seat and eat with him." He described clear situations, vivid images with colors and movement and in which the subjects spoke to him, as if they were real. At first he experienced "anger and frustration, they were his son, his wife... but why they did not listen to me?" Eventually he learned to differentiate them from reality: "those characters spoke and acted ignoring him, they talked and moved around as if I wasn't there." A psychiatric evaluation of the patient was then carried out, who at all times had remained in a good state of consciousness and orientation. He referred a year evolution of visual and auditory hallucinations, currently identified as unreal but real until that moment and that did not create any kind of anguish or emotional repercussion.

Hallucinations occurred during the day and at night and were not associated with sleep disturbances, agitation or vision deficits. Attention, memory, language and cognition were intact (his Mini-Mental State Examination score was 30/30). There were no anxious or mood alterations, nor in the instincts. The patient verbalized fear of expressing these phenomena before that time "They would have taken me crazy!!” Therefore, a conservative treatment was carried out, explaining him the origin of these visions and reassuring him. Since they did not produce at the present time any type of repercussion at a behavioral or affective level, it was decided not to apply any pharmacological treatment.

A search in Pubmed was conducted on similar cases with the words "peduncullar hallucination or hallucinosis or psychosis and thalamic stroke or infarction or ischemia". Only 16 published reviews were found. In most cases there were multifocal lesions, including in most of them the midbrain and the hallucinations were of the "liliputian" type (See table 1).

We found a clear association of the condition with alterations in blood pressure in 6 of the 17 cases described in the form of malignant or uncontrolled hypertension due to organic cause or due to poor compliance with the treatment. Also in more than half of the cases there was a chronic kidney disease diagnosed of advanced degree and in almost all of them a concomitant diabetes mellitus. Delgado., et al. describe a case of hallucinations of thalamic origin but also with damage at the mesencephalic level in which the patient develops complex visual and auditory hallucinations, vivid and with a fantastic component (monsters, shadows...), to this type of hallucinations they call "disorteidolias" [16].

Only one case of those found had any type of previous psychopathology or were in follow-up in psychiatry [17]. 


\begin{tabular}{|c|c|c|c|c|c|c|c|c|c|c|c|c|}
\hline Author & Age & Sex & $\begin{array}{c}\text { Medical pa- } \\
\text { thologies }\end{array}$ & $\begin{array}{l}\text { Neurological } \\
\text { Symptoms }\end{array}$ & $\begin{array}{l}\text { Sleep dis- } \\
\text { turbances }\end{array}$ & Peduncular damage & Visual hallucinosis & $\mathbf{A H}$ & $\begin{array}{l}\text { Treat- } \\
\text { ment }\end{array}$ & PD & $\begin{array}{c}\text { Tox- } \\
\text { ic }\end{array}$ & $\begin{array}{l}\text { Dura- } \\
\text { tion }\end{array}$ \\
\hline $\begin{array}{l}\text { Delgado., } \\
\text { et al. } 2013\end{array}$ & 61 & M & Obesity & Paresthesias & No & $\begin{array}{l}\text { Thalamic stroke (dor- } \\
\text { somedial nucleous), } \\
\text { sparing the intrala- } \\
\text { minar nuclei and the } \\
\text { midbrain }\end{array}$ & No & No & No & No & No & 2 weeks \\
\hline $\begin{array}{l}\text { Speigel., et } \\
\text { al. } 2011\end{array}$ & 77 & $\mathrm{~F}$ & Hyperlipemia & $\begin{array}{c}\text { Headache, } \\
\text { diplopia and } \\
\text { ptosis }\end{array}$ & No & $\begin{array}{l}\text { Acute/subacute right } \\
\text { midbrain infarct. }\end{array}$ & Lilliputian & No & $\begin{array}{c}\text { Yes } \\
\text { Olan- } \\
\text { zapine }\end{array}$ & No & No & 3 weeks \\
\hline \multirow[t]{3}{*}{$\begin{array}{l}\text { Mocellin., } \\
\text { et al. } 2006\end{array}$} & 85 & $\mathrm{~F}$ & $\begin{array}{l}\text { Hypertension, } \\
\text { Hypercho- } \\
\text { lesterolemia, } \\
\text { Diabetes }\end{array}$ & $\begin{array}{l}\text { Visual im- } \\
\text { pairment } \\
\text { (15 years, } \\
\text { glaucoma) }\end{array}$ & No & $\begin{array}{l}\text { Multiple subcortical } \\
\text { white matter lesion } \\
\text { and bilateral lesions } \\
\text { in the pons }\end{array}$ & $\begin{array}{l}\text { Yellow and pink flow- } \\
\text { ers, disembodied and } \\
\text { grimacing male faces, } \\
\text { mainly that of a James } \\
\text { Bond actor appearing } \\
\text { in the bodies of family } \\
\text { members, uniformed } \\
\text { children around the hos- } \\
\text { pital bed }\end{array}$ & No & $\begin{array}{c}\text { Yes } \\
\text { Olan- } \\
\text { zapine }\end{array}$ & No & No & 2 days \\
\hline & 68 & $\mathrm{~F}$ & $\begin{array}{l}\text { Hypertension, } \\
\text { Hypercholester- } \\
\text { olemia }\end{array}$ & $\begin{array}{l}\text { Frontal Hem- } \\
\text { orrhage (38 } \\
\text { years age) }\end{array}$ & No & $\begin{array}{l}\text { Right thalamus lacu- } \\
\text { nar infarct }\end{array}$ & $\begin{array}{c}\text { Unusually small chil- } \\
\text { dren dressed in colorful } \\
\text { uniforms }\end{array}$ & No & $\begin{array}{l}\text { Yes } \\
\text { Risperi- } \\
\text { done }\end{array}$ & No & No & 3 weeks \\
\hline & 33 & $\mathrm{~F}$ & $\begin{array}{l}\text { Arteriovenous } \\
\text { malformation }\end{array}$ & $\begin{array}{l}\text { Left tempo- } \\
\text { roparietal ar- } \\
\text { teriovenous } \\
\text { malformation } \\
\text { (embolized } \\
\text { when } 25 \\
\text { years age), } \\
\text { migraine }\end{array}$ & No & $\begin{array}{l}\text { Midtemporal epilep- } \\
\text { tiform focus }\end{array}$ & $\begin{array}{l}\text { Disembodied faces and } \\
\text { torsos floating (moving } \\
\text { their lips like talking } \\
\text { to her), red letters on } \\
\text { people`s faces and her } \\
\text { own face in the mirror, } \\
\text { hundreds of little spikes } \\
\text { and small ants moving } \\
\text { (predominantly in the } \\
\text { right visual field), }\end{array}$ & No & $\begin{array}{l}\text { Yes } \\
\text { Phen- } \\
\text { itoin }\end{array}$ & No & No & 1 week \\
\hline $\begin{array}{l}\text { Danziger., } \\
\text { et al. } 1997\end{array}$ & 56 & M & Aortic stenosis & No & & $\begin{array}{l}\text { Unilateral infarct } \\
\text { restricted to the } \\
\text { cerebellum, rostral } \\
\text { protuberance and } \\
\text { posterior thalamus. }\end{array}$ & n.e & No & No & No & No & 1 day \\
\hline $\begin{array}{c}\text { Serra } \\
\text { Catafau., et } \\
\text { al. } 1992\end{array}$ & 68 & M & Unknown & $\begin{array}{l}\text { Hemiparesis, } \\
\text { paraesthesias } \\
\text { on the left } \\
\text { side }\end{array}$ & No & $\begin{array}{l}\text { Right posterior tha- } \\
\text { lamic infarct as the } \\
\text { sole lesion. }\end{array}$ & n.e & No & No & No & No & 5 days \\
\hline $\begin{array}{l}\text { Feinberg., } \\
\text { et al. } 1989\end{array}$ & 83 & M & Diabetes & No & & $\begin{array}{l}\text { MRI: Paramedial } \\
\text { right thalamic infarc- } \\
\text { tion without anor- } \\
\text { mality of cerebral pe- } \\
\text { duncles or midbrain }\end{array}$ & n.e & No & No & No & No & 3 days \\
\hline $\begin{array}{c}\text { Kölmel, } \\
1990\end{array}$ & 56 & M & Heart disease & Diplopia & Yes & $\begin{array}{l}\text { Bilateral ischemic le- } \\
\text { sion in thalamus and } \\
\text { mesencephalon }\end{array}$ & n.e & Yes & Yes (n.e) & No & No & $\begin{array}{c}>24 \\
\text { hours }\end{array}$ \\
\hline
\end{tabular}




\begin{tabular}{|c|c|c|c|c|c|c|c|c|c|c|c|c|}
\hline $\begin{array}{l}\text { Mollet., et } \\
\text { al. } 2007\end{array}$ & 61 & $\mathrm{~F}$ & $\begin{array}{l}\text { Hyperlipidemia, } \\
\text { morbid obesity, } \\
\text { hypothyroid- } \\
\text { ism, hyperten- } \\
\text { sion, coronary } \\
\text { artery disease, } \\
\text { and diabetic } \\
\text { peripheral } \\
\text { neuropathy }\end{array}$ & & No & Right thalamic stroke & College boys & Yes & No & Yes & No & n.e \\
\hline $\begin{array}{l}\text { Fornaz- } \\
\text { zari., et al. } \\
\quad 2012\end{array}$ & 45 & M & Hypertension & $\begin{array}{c}\text { Memory } \\
\text { impairment }\end{array}$ & No & $\begin{array}{l}\text { Left lateral poste- } \\
\text { rior nucleus of the } \\
\text { thalamus }\end{array}$ & $\begin{array}{l}\text { Sound-tactile, sound- } \\
\text { color, and grapheme- } \\
\text { gustatory synesthesia }\end{array}$ & No & No & No & Yes & $\begin{array}{c}9 \\
\text { months }\end{array}$ \\
\hline $\begin{array}{l}\text { Badrin., et } \\
\text { al. } 2017\end{array}$ & 73 & M & $\begin{array}{l}\text { Diabetes and } \\
\text { hypertension }\end{array}$ & No & Yes & Right thalamus & n.e & Yes & $\begin{array}{l}\text { Yes } \\
\text { Risperi- } \\
\text { done, } \\
\text { ISRS }\end{array}$ & No & No & $\begin{array}{l}\text { Un- } \\
\text { known }\end{array}$ \\
\hline $\begin{array}{l}\text { Liao., et al. } \\
\quad 2018\end{array}$ & 67 & $\mathrm{~F}$ & $\begin{array}{l}\text { Hypertension, } \\
\text { hyperlipidemia }\end{array}$ & $\begin{array}{l}\text { Ataxia, dys- } \\
\text { arthria, scan- } \\
\text { ning speech }\end{array}$ & No & $\begin{array}{l}\text { Bilateral and cerebel- } \\
\text { lum }\end{array}$ & Persecutory delusions & No & $\begin{array}{l}\text { Halo- } \\
\text { peridol }\end{array}$ & No & No & $\begin{array}{c}2 \\
\text { months }\end{array}$ \\
\hline $\begin{array}{l}\text { Santos., et } \\
\text { al. } 2009\end{array}$ & 49 & M & $\begin{array}{c}\text { Lymphoblastic } \\
\text { leukemia }\end{array}$ & No & No & Left thalamus & $\begin{array}{c}\text { No. Gustative hallucina- } \\
\text { tion }\end{array}$ & No & $\begin{array}{l}\text { Yes que- } \\
\text { tiapine }\end{array}$ & No & $\begin{array}{c}\text { Alco- } \\
\text { hol }\end{array}$ & $\begin{array}{c}3 \\
\text { months }\end{array}$ \\
\hline $\begin{array}{l}\text { Crail Me- } \\
\text { lendez., et } \\
\text { al. } 2013\end{array}$ & 37 & $\mathrm{~F}$ & Unknown & No & No & $\begin{array}{l}\text { Posterior region of } \\
\text { the right thalamus }\end{array}$ & Persecutory delusions & No & $\begin{array}{l}\text { Yes, } \\
\text { Risperi- } \\
\text { done }\end{array}$ & No & $\begin{array}{l}\text { To- } \\
\text { bac- } \\
\text { co }\end{array}$ & 1 week \\
\hline $\begin{array}{l}\text { Mittal., et } \\
\text { al. } 2010\end{array}$ & 19 & $\mathrm{~F}$ & $\begin{array}{l}\text { Factor V Leiden } \\
\text { mutation }\end{array}$ & No & No & Left thalamus & Ex boyfriend & No & $\begin{array}{l}\text { Yes } \\
\text { Risperi- } \\
\text { done }\end{array}$ & No & No & $\begin{array}{c}1 \\
\text { month }\end{array}$ \\
\hline $\begin{array}{l}\text { McGil- } \\
\text { christ., et } \\
\text { al. } 1993\end{array}$ & 43 & M & Unknown & No & Yes & $\begin{array}{l}\text { Bilateral thalamic } \\
\text { infarction }\end{array}$ & $\begin{array}{l}\text { Delusions of self-refer- } \\
\text { ence and grandiosity } \\
\text { and visual hallucina- } \\
\text { tions. }\end{array}$ & No & $\begin{array}{l}\text { Yes } \\
\text { Lithium }\end{array}$ & No & No & $\begin{array}{c}18 \\
\text { months }\end{array}$ \\
\hline $\begin{array}{l}\text { Arikan., et } \\
\text { al. } 2009\end{array}$ & 33 & M & Unknown & $\begin{array}{l}\text { Speaking, } \\
\text { learning and } \\
\text { concentration } \\
\text { difficulties }\end{array}$ & No & $\begin{array}{l}\text { Left thalamic lacunar } \\
\text { infarcts }\end{array}$ & $\begin{array}{l}\text { Auditory hallucinations } \\
\text { and delusions of perse- } \\
\text { cution }\end{array}$ & No & $\begin{array}{l}\text { Yes, } \\
\text { Risperi- } \\
\text { done }\end{array}$ & No & No & 2 weeks \\
\hline
\end{tabular}

Table 1: Articles that includes case reports of peduncular hallucinosis and thalamic stroke.

Note: F: Female; M: Male; n.e: Not Specified; AH: Auditory Hallucinosis; PD: Psychiatric Disorder.

In a majority of the reviewed cases it is necessary to administer some type of pharmacological treatment, especially if the symptoms are accompanied by behavioral or personality changes. Risperidone is the antipsychotic that has been most frequently used in those patients in whom pharmacological treatment has been necessary [18-21]. However we found a published case in which the use of olanzapine quetiapine at low doses or even lithium had a satisfactory effect for their control [18,22,23].
Synesthesias were reported in two of the cases analyzed [22,24].

As in our case Kolmel., et al. also described a single thalamic lesion on the CT scan and hallucinations are also indistinguishable. Another differential factor was that despite how vivid they were in both cases, indistinguishable from reality, as in our patient, in the published case corresponded with images of the past and included people who had died years ago. 
The main differences with the case we presented was the duration of them, about five years, with a decrease in their intensity and complexity afterwards without the need for specific treatment and which were accompanied by auditory hallucinations.

Also the origin is a unique lesion in the thalamus region not associated with other peripheral ischemic lesions.

\section{Conclusion}

We present an updated review of the literature published to date on thalamic infarction accompanied by psychotic symptomatology. Mainly we find descriptions of classic cases and only two cases published in the last 5 years. We analyze the common and differential characteristics of each of them in order to understand and redefine the concept of peduncular hallucinations secondary to thalamic ischemic events.

The classic descriptions of authors such as Feinberg in 1989, present data of a patient with a pyramidal right thalamic infarction that presented vivid hallucinations. Serra Catafau in 1992, describes visual hallucinations in a patient with a posterior thalamic infarction.

In the first description of Lhermitte, they appear as associated with sleep disorders, although we only found that association in three of the cases we have analyzed [1,19,22].

Although the exact pathogenesis of peduncular hallucinations is still unknown, in most cases it affects the midbrain or thalamus, and in the majority of published cases it appears after a heart attack that damages these structures. Half of the cases there are some other neurological deficits, like paresthesias [16] diplopia and ptosis $[21,25]$ ataxia or dysarthria $[20,26]$. Nor are there other alterations in the higher cognitive functions of attention, concentration, orientation, consciousness or intellect. There are no other accompanying mental symptoms that suggest psychopathological alterations.

Because sleep disturbances often accompanied the visual hallucinations, Lhermitte believed that peduncular hallucinosis resulted from the pathological release of subcortical regions that are active in dreaming, while consciousness remained intact. In addition to lesions in the midbrain, injury to the pulvinar nucleus of the thalamus and lower pons also has been associated with complex visual hallucinations, raising the possibility that this condition may arise from disruption of subcortical visual processing pathways or a diffuse cerebral reaction to various lesions in primitive structures.

A significant overlaps exists between the concepts of Charles Bonnet Syndrome and PH. The fluidity of these eponymous syndromes reduces their validity and meaning, and may result in an inappropriate attribution of the underlying pathology. Charles Bonnet Syndrome describes a group of patients with visual hallucinations in the setting of visual loss, and shows significant clinical overlap with PH. An understanding of how differing pathologies may produce complex visual hallucinosis allows the appropriate understanding of treatment, depending on the site and nature of the lesion and content of perceptual disturbance [18] (See table 2). According the literature reviewed so far, we understand that an exhaustive ophthalmological study of patients would be recommended in this type of case to make a differential diagnosis with Charles Bonnet Syndrome $[27,28]$.

\begin{tabular}{|l|c|}
\hline Peduncular hallucinosis & Charles Bonnet syndrome \\
\hline $\begin{array}{l}\text { Percepts predominantly } \\
\text { visual }\end{array}$ & Percepts predominantly visual \\
\hline $\begin{array}{l}\text { Percepts vivid, formed and } \\
\text { colorful }\end{array}$ & $\begin{array}{c}\text { Percepts vivid, formed and color- } \\
\text { ful }\end{array}$ \\
\hline $\begin{array}{l}\text { May include Lilliputian } \\
\text { phenomena }\end{array}$ & $\begin{array}{c}\text { May include Lilliputian phenom- } \\
\text { ena }\end{array}$ \\
\hline $\begin{array}{l}\text { Stimuli animate, mobile and } \\
\text { non-stereotypical }\end{array}$ & \multicolumn{1}{|c|}{\begin{tabular}{c} 
Varied \\
\hline Predominate at night
\end{tabular}} \\
\hline Generally clear sensorium & Predominate at night \\
\hline $\begin{array}{l}\text { May have ocular disease; } \\
\text { Central Nervous System pa- } \\
\text { thology frequently reported }\end{array}$ & $\begin{array}{c}\text { Frequently have ocular disease; } \\
\text { Central Nervous System pathol- } \\
\text { ogy rarely reported }\end{array}$ \\
\hline Occur across age groups & Most common in elderly \\
\hline
\end{tabular}

Table 2: Comparative features of peduncular hallucinosis and Charles Bonnet syndrome.

Regarding treatment in most cases it has been decided not to use antipsychotic treatment because the individuals did not describe them as bothersome and the side effects of the medication in this type of generally aged population could be more harmful.

Therefore, within hallucinatory cases of an organic type, especially in patients with cardiovascular risk factors, it is important to rule out rare syndromes such as Charles Bonnet or hallucinations 
of thalamic origin, being always indicated to perform brain and ophthalmologic imaging tests.

We present, therefore, what we believe is one of the only cases in which a picture of hallucinosis is presented as the origin of a single lesion at thalamus level and the extension of the complex has been prolonged than any case described to date.

It is noteworthy the degree of reality and familiarity that has made our patient live with their symptoms for five years, the longest of the many cases reviewed in the existing bibliography, duration that would include the status designation.

\section{Conflict of Interest}

The authors report no conflict of interest.

\section{Bibliography}

1. Arıkan MK., et al. "A case of psychosis associated with left thalamic lacunar infarcts". Progress in Neuropsychopharmacology and Biological Psychiatry 33.4 (2009): 729-730.

2. Badrin S., et al. "A brief psychotic episode with depressive symptoms in silent right frontal lobe infarct". Korean Journal of Family Medicine 38.6 (2017): 380-382.

3. Bossi L., et al. "Peduncular hallucinosis in a young woman with vertebrobasilar insufficiency based on severe hypoplasia of a vertebral artery, demonstrated angiographically". Archivio per le scienze mediche 137.2 (1980): 347.

4. Caplan LR. "Top of the basilar" syndrome". Neurology 77.21 (2011): 1933.

5. Crail-Melendez D., et al. "Schizophrenia-like psychosis associated with right lacunar thalamic infarct". Neurocase 19.1 (2013): 22-26.

6. Danziger N., et al. "Visual hallucinosis and hyperhedonism in pontine and thalamic infarction". Revue neurologique 153.11 (1997): 679-683.

7. Delgado M G and Bogousslavsky J. “'Distorteidolias' - fantastic perceptive distortion. A new, pure dorsomedial thalamic syndrome". European Neurology 70 (2013): 6-9.

8. de Morsier $\mathrm{G}$ and Congrès international de neurologie (2: 1935: London). Pathogénie de l'hallucinose pédonculaire: à propos d'un nouveau cas (1935).

9. Feinberg WM and Rapcsak SZ. 'Peduncular hallucinosis' following paramedian thalamic infarction". Neurology 39.11 (1989): 1535.
10. Fornazzari L., et al. "“Blue is music to my ears": Multimodal synesthesias after a thalamic stroke". Neurocase 18.4 (2012): 318-322.

11. Kölmel HW. "Peduncular hallucinations". Journal of Neurology 238.8 (1991): 457-459.

12. Kumar R., et al. "Peduncular hallucinosis: An unusual sequel to surgical intervention in the suprasellar region". British Journal of Neurosurgery 13.5 (1999): 500-503.

13. Leiva-Santana C., et al. "Peduncular hallucinosis associated with a space occupying lesion of the brain stem". Revista de neurologia 28.12 (1999): 1174-1176.

14. Lhermitte J. "Syndrome de la calotte du pedoncule cerebral. Les troubles psycho-sensoriels dans les lesions du mesocephale". Revue neurologique (Paris): 38 (1922): 1359-1365.

15. Liao P., et al. "Onset of psychosis following strokes to the cerebellum and thalamus". Psychosomatics 59.4 (2018): 413-414.

16. Maiuri F., et al. "Peduncular hallucinations associated with large posterior fossa meningiomas". Clinical Neurology and Neurosurgery 104.1 (2002): 41-43.

17. McGilchrist, I., et al. "Thalamo-frontal psychosis". The British Journal of Psychiatry 163.1 (1993): 113-115.

18. Mittal M and Khan S. "Starvation causes acute psychosis due to anterior thalamic infarction”. Southern Medical Journal 103.7 (2010): 701-703.

19. Miyazawa T., et al. "Peduncular hallucinosis due to a pineal meningioma. case report”. Journal of Neurosurgery 95.3 (2001): 500.

20. Mocellin R., et al. "Neuropsychiatry of complex visual hallucinations". Australian and New Zealand Journal of Psychiatry 40.9 (2006): 742-751.

21. Mollet GA., et al. "Asymmetry in the emotional content of lateralised multimodal hallucinations following right thalamic stroke". Cognitive Neuropsychiatry 12.5 (2007): 422-436.

22. Rozanski J. "Peduncular hallucinosis following vertebral angiography”. Neurology 2.4 (1952): 341.

23. Santos S., et al. "Stroke-psychosis. Description of two cases". Actas espanolas de psiquiatria 37.4 (2009): 240.

24. Serra Catafau J., et al. "Peduncular hallucinosis associated with posterior thalamic infarction". Journal of Neurology 239.2 (1992): 89-90. 
25. van Bogert L. "La hallucinose pedunculaire". Revue neurologique (Paris) 43 (1927): 608-617.

26. Yano K., et al. "Delayed cerebral ischemia manifesting as peduncular hallucinosis after aneurysmal subarachnoid hemorrhage -three case report". Neurologia Medico-Chirurgica 34.9 (1994): 593-596.

27. Podoll $\mathrm{K}$ and Robinson D. "Recurrent lilliputian hallucinations as visual aura symptom in migraine". Cephalalgia 21.10 (2001): 990-992.

28. Spiegel D., et al. "A potential case of peduncular hallucinosis treated successfully with olanzapine". Clinical Schizophrenia and Related Psychoses 5.1 (2011): 50-53.

\section{Assets from publication with us}

- Prompt Acknowledgement after receiving the article

- Thorough Double blinded peer review

- Rapid Publication

- Issue of Publication Certificate

- High visibility of your Published work

Website: www.actascientific.com/

Submit Article: www.actascientific.com/submission.php

Email us: editor@actascientific.com

Contact us: +919182824667 